\title{
The Application of E-Commerce on Fashion Shop
}

\author{
A Rachmanto $^{1}$, A Kurniawan ${ }^{2}$ \\ \{adi.rachmanto@email.unikom.ac.id ${ }^{1}$, andrikurniawannn23@mahasiswa.unikom.ac.id ${ }^{2}$ \} \\ ${ }^{1}$ Department of Economics and Business, Universitas Komputer Indonesia, Indonesia \\ ${ }^{2}$ Department of Engineering and Computer Science, Universitas Komputer Indonesia, \\ Indonesia.
}

\begin{abstract}
The purpose of this study is to know how much level the consumer needs for the distribution that has been implemented in e-commerce technology. In this modern era, ecommerce technology has been widely implemented among people in business to develop online business. The method used in this research is descriptive method by creating a short and accurate method based on the field results. The result of this research is to know whether the XYZ store in Bandung needs an online e-commerce application and provides knowledge about the excellence of e-commerce applications. This research is based on how to discuss problems experienced by businessmen and the systems that will be applied to ecommerce applications. The goal of this paper is to implement a Web-based e-commerce business in a fashion store.
\end{abstract}

Keywords : E-Commerce, Information System, Online Business, Ease Of Purchase

\section{Introduction}

E-commerce is the usage of the internet and also the web as a formal business transaction and defined as trading transactions. So, E-commerce relates to buy and sell transactions done digitally using a computer connected to the Internet [1]. According to Eddy Soeryanto Soegoto, information technology makes the business more responsive, fast, easy, cheap, efficient, effective, transparent, and flexible in modern business systems to improve performance, competitive advantage, and profitability of the company [2].

E-commerce is a dynamic series of interconnected technologies, applications, and business processes between companies, consumers and specific communities using electronic transaction methods and trading of goods, services, and information Done electronically [3]. Ecommerce is defined as the purchase and sale of goods and services by using online consumer services on the Internet. The transaction Model is also called electronic transaction [4]. Ecommerce is a process undertaken by consumers in buying and selling products electronically from companies to companies, individuals, or other communities using computers as intermediaries for business transactions [5]. E-commerce refers to the Internet network to do online shopping and narrower reach, as well as how to conduct transactions via digital money transfer [6].

E-commerce includes trade transactions through electronic media. In other words, not only the internet is intended, but it also includes all trade transactions through other electronic media such as fax, telex, EDI and telephone [7]. Electronic commerce or E-commerce is also known as commercial transactions between vendors and purchases or parties in similar 
contractual relationships for the supply of goods, services or "true" acquisitions. These commercial transactions are carried out or entered into electronic or digital media, where the physical presence of parties is not needed, and the media is on the network or public system as opposed to private networks (closed systems). Public network systems must be reconsidered when the system is open (for example the internet). The transaction is agreed without national boundaries or local requirements [8]. Kosiur revealed that e-commerce is not only a mechanism for the sale of items or services through the internet medium but rather a business transformation that changes how companies conduct their daily business activities [9]. The purpose of introducing e-commerce is to introduce a new concept that is usually described as the process of buying and selling internet goods or services or the process of buying and selling products or services through information networks including the internet [10].

\section{Experimental Method}

This study uses a descriptive method in knowing the variables associated with ecommerce and online businesses. In order to find out and analyze how influential ecommerce is to the business world.

\section{Results and Discussion}

To facilitate the user or the buyer to access the site in the online business world, the seller can also upload and provide information and explanations about the offered products. For example, for an online business that offers fashion products, it is advisable to explain in detail the product from head to toe products such as hats, clothes, jackets, or pants. The payment method is done by indirect transactions and ordering the product which then paid using ATM transfer [11].

Transactions can also be done anytime and anywhere, and follow the wishes of buyers who can access through browsing the internet on various electronic devices (Figure 1).

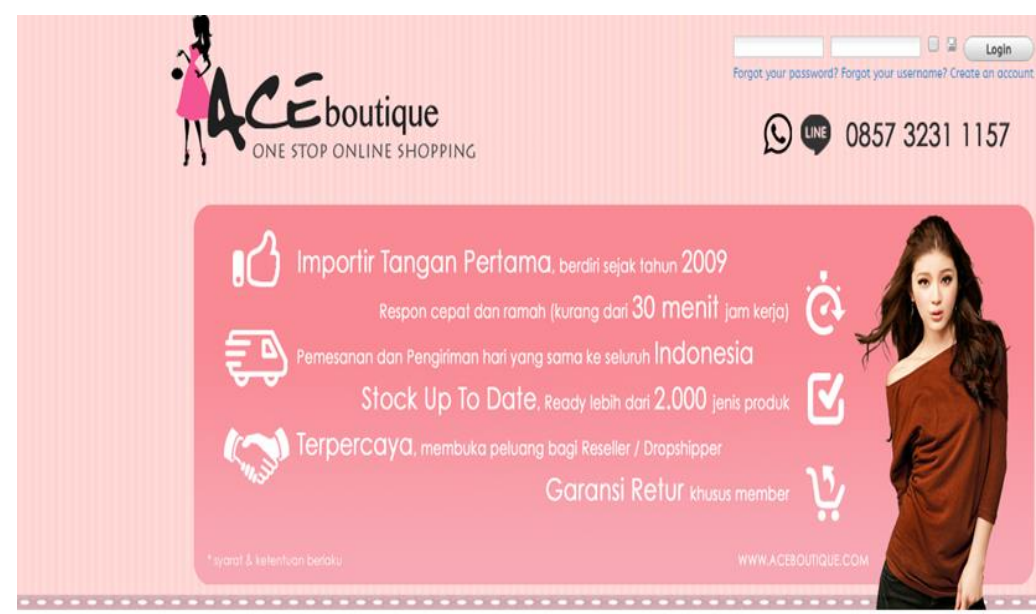

Fig. 1. Login Menu. This Figure was adapted from http://www.aceboutique.com/ on August 16, 2018 . 
There are several parts in the main view such as the login menu and creating a new account. If the buyer already has an account then they can directly select the login menu and if the buyer does not have an account, then the buyer have to choose the create an account menu (Figure 2).

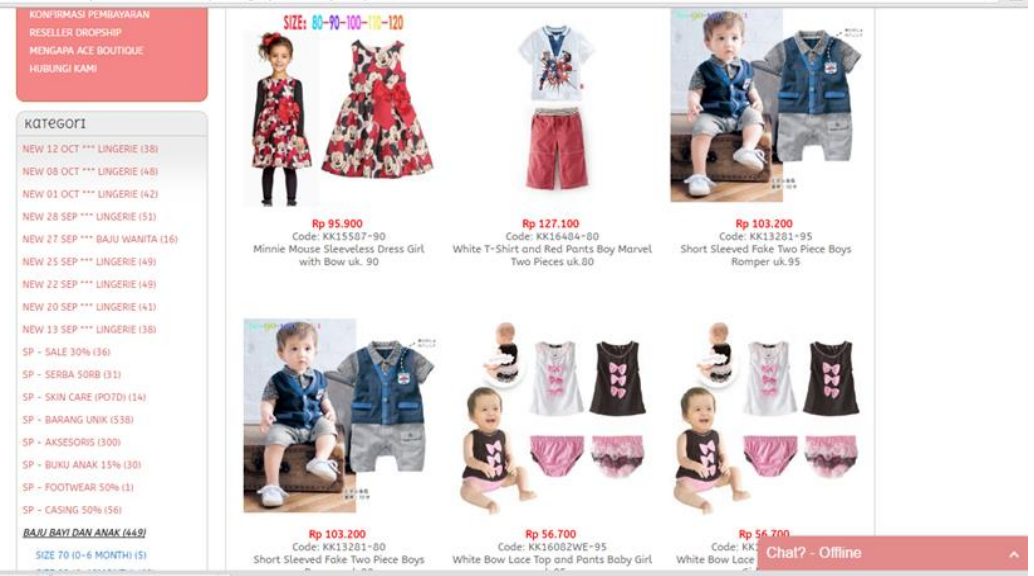

Fig 2. Product Menu. This Figure was adapted from http://www.aceboutique.com/ on August 16,2018

In the product view, buyers can search for the desired product. The products on the website are local and foreign products in which the prices and product names are listed at the corner of the product image. On the bottom of the website is customer service contact, buyers can chat or request information about the product during working hours. This is in line with the research done by Alivia. A., Nature. I. S., and Rinta. K., where the e-Commerce application designers are required to have a functional \& non-functional feature that should be provided [12] (Figure 3).

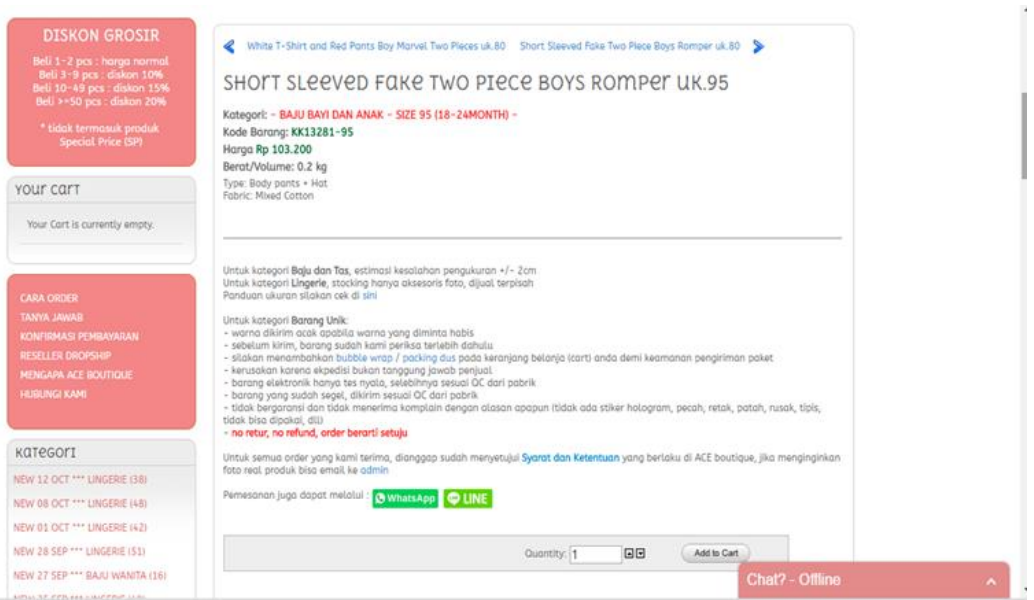

Fig 3. Product Information Menu. This Figure was adapted from http://www.aceboutique.com/ on August 16, 2018.

After the user clicked the desired item, the user can select the product to buy it. This menu contains information about the brand, price, and information on how to buy the item. Users 
also get information about the type of item or product specifications so users will know what items to buy (Figure 4).

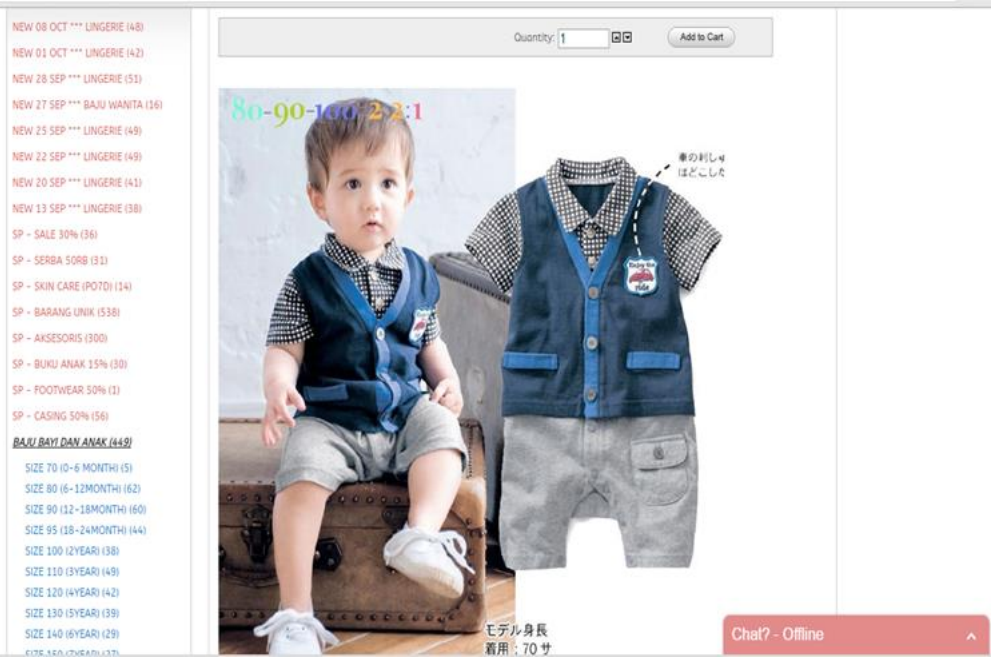

Fig 4. Order Menu. This Figure was adapted from http://www.aceboutique.com/ on August 16, 2018.

In this context, the user is given a feature to choose how many items will be purchased and is presented with a clearer and more specific product picture. If the user wants the product, the user can make a transaction through the media WhatsApp. Then it will continue to the transfer transaction (Figure 5).

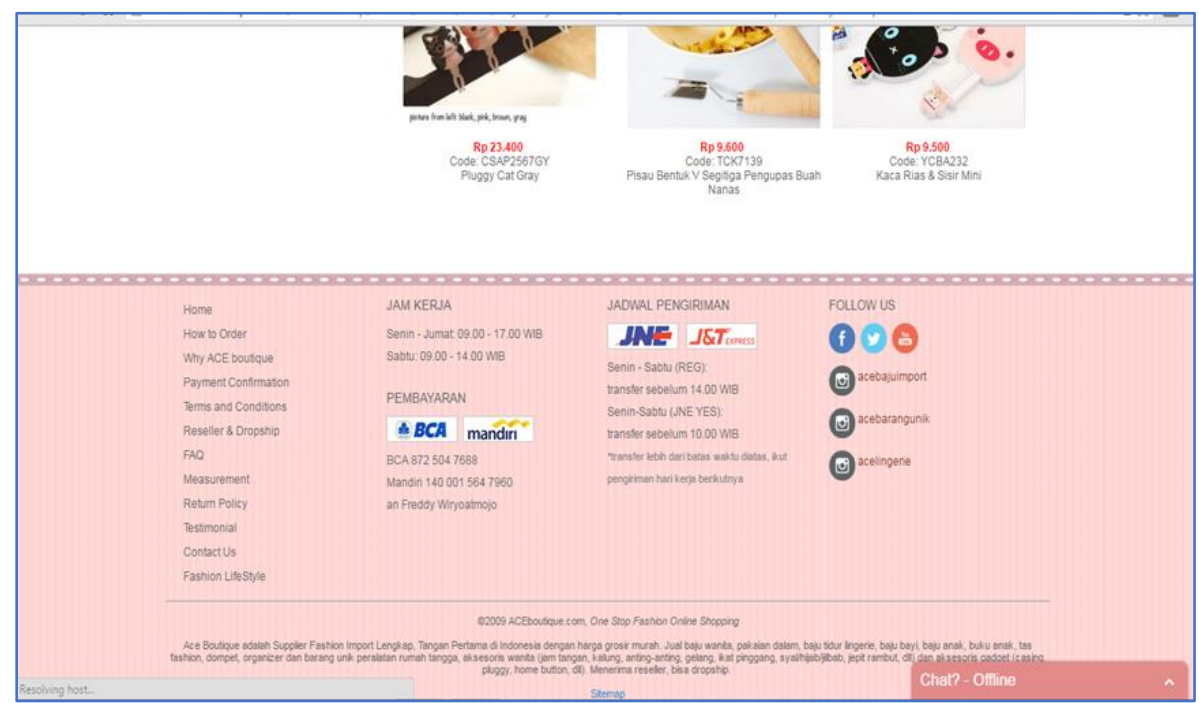

Fig 5. Information Table. This Figure was adopted from http://www.aceboutique.com/ on August 16, 2018. 
Users will find out what is on the web and look for information about delivery schedules, working hours, payment methods, and social media used by this site. This concept is according to what Riyeke Ustadiyanto expressed that E-commerce is a trade interaction between sellers and buyers who use Internet media, in the process of ordering goods transactions, payment of transactions until delivery Goods are communicated via the Internet. [13].

\section{Conclusion}

Technological advances are very helpful in today's society, not only making it easier for shoppers but also for business owners. With this web-based technology, business owners will easily promote the items they sell and expand the marketing range of these products. Another advantage for customers is the ease to buy the products they want. Customers don't need to come to the store or go out of their house. With the advancement of this technology, users could just access the Internet and immediately search for whatever items they need. About the payment, the customer can just transfer the money through the ATM. So, the owners and users alike get their own benefits.

\section{References}

[1] Jonathan,S. Prihartono,A.H,: Perdagangan online: cara bisnis di internet, hak cipta dilindungi undang-undang, 2012

[2] Soegoto, E. S, : Enterpreneurship Menjadi Pembisnis Ulung (Edisi Revisi). Kompas Gramedia. Jakarta. 2010

[3] Baum D,: E-Commerce. New Jersey : Oracle Corp, 1999

[4] Ding, J.: E-Commerce Law and Office, Bandung: Sweet and Maxwell Asia, 1999

[5] Laudon, J., dan Laudon, K. C.: Essential Of Management Information System. Prentice Hall. New jersey. 1998

[6] Kalakota, R and Whinston, A.B,: Electronic Commerce: A Manager's Guide. New Jersey: AddisonWesley Professional. 1997.

[7] Yahya, AZ.: Kontrak Elektronik \& Penyelesaian Sengketa Bisnis E-Commerce dalam Transaksi Nasional \& Internasional. Bandung. Mandar Maju. 2009.

[8] Julian D, :E-Commerce:Law and Office, Malaysia, Sweet and Maxwell Asia, Hal.25 , 1999.

[9] David K, : Understanding Electronic Commerce, Washington, Microsoft Press,Hal.24, 1997.

[10] Shi, Q, Siegel, Siegel,: dalam buku M.Suyanto (2003:11) dan (Turban, Lee, King, Chung, 2000) dalam buku Suyanto (2003:11), 2000.

[11] Soegoto, E. S., \& Nurwahan, I. B.: Designing Student Aspiration Website with PHP. In IOP Conference Series: Materials Science and Engineering (Vol. 407, No. 1, p. 012028).

[12] Alivia.A, Kodrat. IS., Rinta.K, : Perancangan Aplikasi Toko Online "XO-Licios" Berbasis Mobile Web pada Sistem Operasi Android, Jurnal Teknologi dan Sistem Komputer (Vol.1, No.4), 2013.

[13] Riyeke U ,: FrameWork E-Commerce Andi Yogyakarta. 2002. 